\title{
Studi Tentang Optimasi Peletakan Anjungan Minyak Lepas Pantai
}

\author{
Rafli Maulana dan Khomsin \\ Jurusan Teknik Geomatika, Fakultas Teknik Sipil dan Perencanaan, Institut Teknologi Sepuluh Nopember (ITS) \\ J1. Arief Rahman Hakim, Surabaya 60111 Indonesia \\ e-mail : khomsin@geodesy.its.ac.id
}

\begin{abstract}
Abstrak-Bangunan atau anjungan lepas pantai (offshore platform) adalah struktur atau bangunan yang dibangun di lepas pantai untuk mendukung proses eksplorasi atau eksploitasi bahan tambang maupun mineral alam.

Penelitian ini menganalisis tentang perencanaan peletakan anjungan minyak lepas pantai dengan menggunakan data yang diperoleh dari alat Multibeam Echosounder, Side Scan Sonar, dan Magnetometer. Dari penelitian ini bertujuan untuk mengidentifikasi kondisi permukaan dasar laut (fitur-fitur dasar laut) dan potensi bahaya serta memberikan rekomendasi lokasi rencana peletakan anjungan minyak lepas pantai.

Analisis dilakukan berdasarkan kemiringan dasar laut, potensi bahaya, fitur-fitur dasar laut baik yang berada di permukaan dasar laut maupun logam yang terkubur di dasar laut sehingga dapat membahayakan anjungan minyak lepas pantai.

Berdasarkan penelitian ini, terdapat lokasi yang direkomendasikan, tidak direkomendasikan dan berbahaya. Lokasi yang direkomendasikan merupakan lokasi yang bebas dari hazard, anomali magnetik dan slope yang datar, dengan skor 0.333 dan lokasi yang tidak direkomendasikan merupakan lokasi dengan slope yang landai, potensi bahaya dengan skor 0.334 - 0.666 serta lokasi yang berbahaya merupakan lokasi dengan slope $>3^{\circ}$, terdapat anomali magnetik dan potensi bahay dengan skor 0.6667 - 1.332. Luas area yang direkomendasikan adalah untuk anjungan minyak lepas pantai seluas 532.925,372 $\mathbf{m}^{2}$ dan luas area yang tidak direkomendasikan untuk anjungan minyak lepas pantai seluas $467.074,628 \mathrm{~m}^{2}$.
\end{abstract}

Kata Kunci-Anjungan Minyak Lepas Pantai, Multibeam Echosounder, Side Scan Sonar, Magnetometer, Fitur - Fitur Dasar Laut

\section{PENDAHULUAN}

$\mathrm{B}$ ANGUNAN atau anjungan lepas pantai (offshore platform) adalah struktur atau bangunan yang di bangun di lepas pantai untuk mendukung proses eksplorasi atau eksploitasi bahan tambang maupun mineral alam (kemenperin.go.id). Fungsi utama dari platform adalah untuk eksploitasi dan produksi minyak dan gas bumi. Adapun faktor lingkungan laut yang berpengaruh untuk rancangan struktur bangunan laut terdiri dari kedalaman perairan, angin, gelombang, arus, kondisi dasar laut, dan penggerusan serta tektonik (gempa bumi). Instalasi dari anjungan minyak lepas pantai membutuhkan proses-proses tertentu, meliputi studi seismik, survei seismik, pemilihan reservoir, site survey atau survei lokasi. Survei lokasi adalah survei yang dilakukan untuk memastikan bahwa area yang akan dibangun platform bebas dari potensi bahaya dan fitur-fitur dasar laut yang membahayakan platform. Instalasi anjungan minyak lepas pantai merupakan struktur yang sangat rentan, kompleks, dan biaya konstruksinya sangat mahal sehingga toleransi kegagalan dalam proses instalasinya dibentuk semaksimal mungkin.

Aktivitas utama dalam eksploitasi minyak lepas pantai adalah pengeboran, anjungan lepas pantai harus ditempatkan pada posisi yang sesuai. Untuk peletakan platform, informasi mengenai keadaan di bawah dan di atas permukaan dasar laut sangat diperlukan, aktivitas pengumpulan data ini disebut dengan survei lokasi. Survei lokasi bertujuan untuk memperoleh informasi untuk mendapatkan posisi yang sesuai untuk penempatan platform dan menghindari potensi bahaya bawah laut.

Survei lokasi terdiri dari dari survei hidrografi, survei geofisika, dan survei meteorologi dan oseanografi yang kemudian saling dihubungkan hingga terbentuk suatu analisis mengenai keadaan lokasi pemasangan anjungan minyak lepas pantai tersebut. Terdapat beberapa kriteria aman dalam survei lokasi, sebagai contoh area tersebut harus bersih dari puingpuing bekas instalasi, tidak memiliki shallow gas yang dapat memicu ledakan anjungan minyak lepas pantai karena tekanan gas yang terlalu tinggi, bebas dari bahaya fitur-fitur dasar laut seperti kapal karam, pungguk laut, pipa dan kabel bawah laut, serta ranjau.

Dalam penelitian ini, dilakukan sebuah studi optimasi peletakan anjungan minyak lepas pantai (platform) dengan menggunakan data Multibeam Echosounder, Side Scan Sonar, dan Magnetometer untuk menentukan morfologi dasar laut dan potensi bahaya di lokasi penelitian.

Multibeam Echosounder merupakan sebuah sistem peralatan survei kelautan yang memanfaatkan teknik gelombang akustik. Peralatan ini digunakan untuk memetakan dasar laut yang juga dapat digunakan untuk mempelajari kondisi lingkungan dasar laut. Penggunaan teknologi multibeam echosounder digunakan untuk mengetahui tentang keadaan laut dalam, khususnya penyediaan data kedalaman dan keadaan morfologi dasar laut. Sedangkan Side Scan Sonar digunakan untuk menghasilkan citra dasar laut, yang diaplikasikan untuk investigasi morfologi dasar laut dan pencarian fitur-fitur dasar laut yang dapat membahayakan anjungan minyak lepas pantai.

Magnetometer

merupakan alat yang digunakan untuk survei bawah laut yang mampu mendeteksi variasi-variasi kecil dalam medan magnet bumi yang dihasilkan dari kedekatan obyek magnetik (terutama benda logam). Magnetomoter juga mampu menemukan dan mengidentifikasi endapan maupun puingpuing yang berbahan logam seperi pipa bawah laut, kabel, sampah bekas instalasi baik di permukaan dasar laut maupun yang terpendam dengan cara mendeteksi anomali magnetiknya. Oleh karena itu, dalam penelitian ini akan 
dilakukan penelitian tentang optimasi peletakan anjungan minyak lepas pantai menggunakan Multibeam Echosounder, Side Scan Sonar, dan Magnetometer sehingga dalam penelitian ini dapat memberikan rekomendasi lokasi peletakan survei anjungan minyak lepas pantai.

\section{METODOLOGI PENELITIAN}

Lokasi penelitian berada di Perairan Madura, Provinsi Jawa Timur.

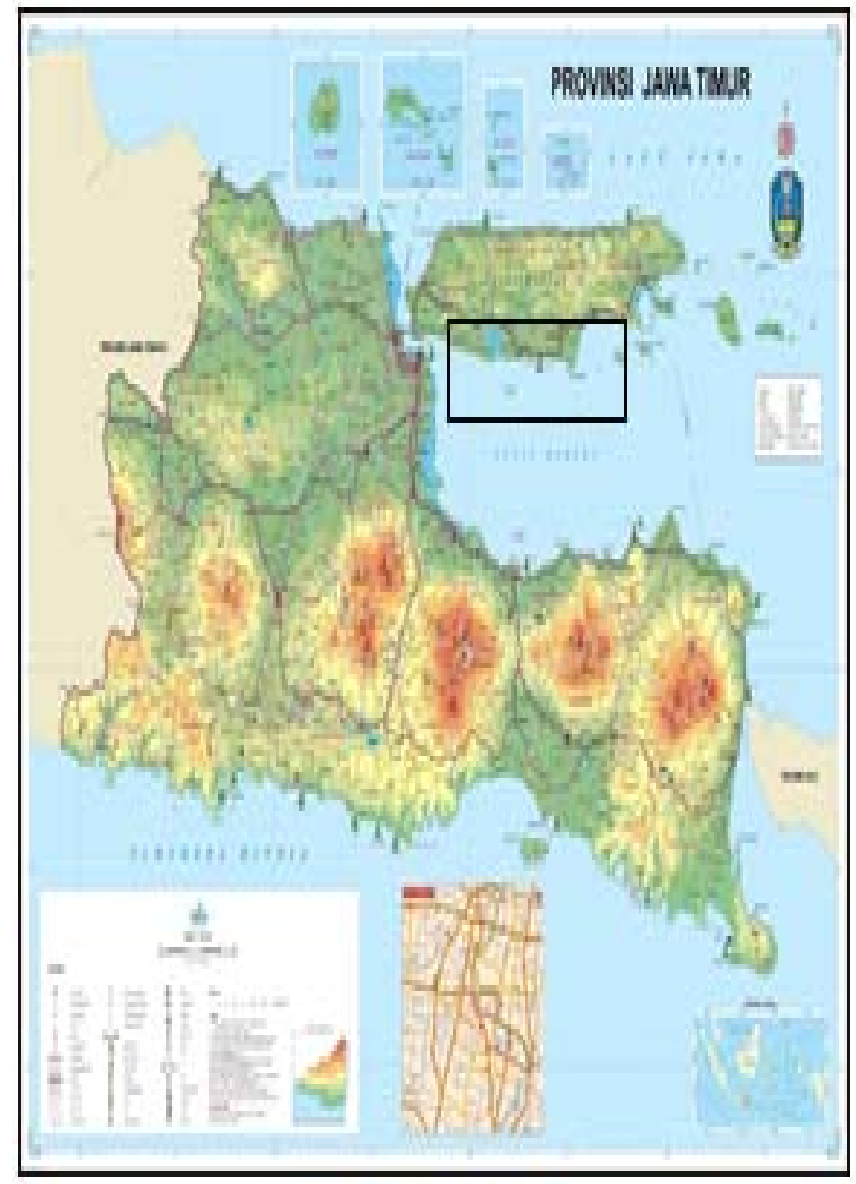

Gambar 1. Lokasi Penelitian

(Sumber : bakosurtanal)

Data yang digunakan dalam penelitian tugas akhir ini yaitu [1]Data Multibeam Echosounder, [2] Data Side Scan Sonar, [3] Data Magnetometer, [4] Data Pasang Surut

Analisa data dilakukan dengan memberikan penilaian (scoring) pada parameter sebagai berikut [1] kemiringan (slope) dasar laut, [2] potensi bahaya, [3] anomali medan magnet.

Penentuan lokasi rekomendasi peletakan anjungan minyak lepas pantai menggunakan skoring dan pembobotan. Pembobotan yang digunakan alat analisa Analytical Hierarcy Process (AHP). Analisa AHP digunakan untuk menentukan bobot tiap kriteria-kriteria yang berpengaruh terhadap lokasi peletakan anjungan minyak lepas pantai. AHP yang digunakan dengan matriks perbandingan pasangan.

\section{HASIL DAN PEMBAHASAN}

A. Hasil

1) Rekomendasi Lokasi Peletakan Anjungan Minyak Lepas Pantai

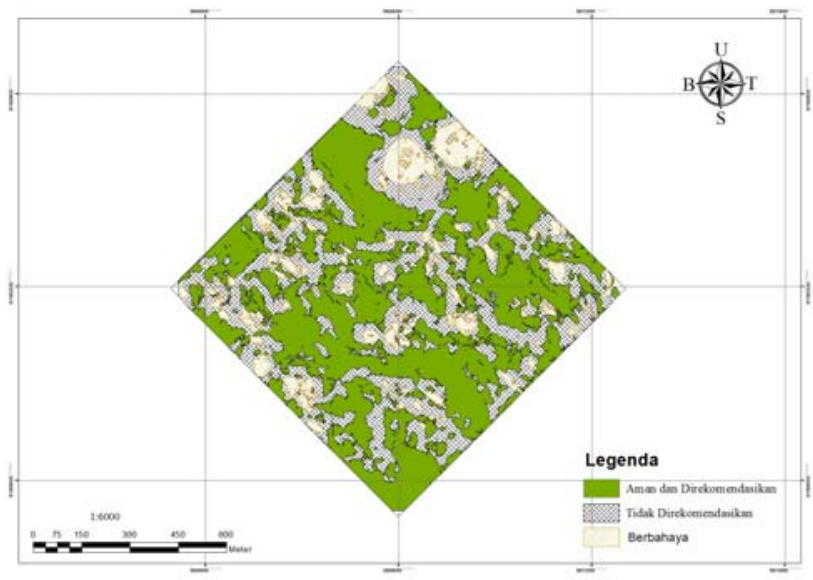

Gambar 2. Peta Rekomendasi Lokasi Peletakan Anjungan Minyak Lepas Pantai

Lokasi peletakan anjungan minyak lepas pantai ini ditinau dari tiga aspek meliputi kemiringan dasar laut (slope), keamanan lokasi dari hazard serta anomali medan magnet. Lokasi yang direkomendasikan untuk peletakan platform tersebut merupakan lokasi yang datar, bebas dari potensi bahaya (hazard) dan anomali medan magnet. Skor masingmasing parameter dioverlaykan sehingga mendapatkan area yang aman untuk peletakan anjungan minyak lepas pantai. Hasil pengolahan datanya berupa peta kemiringan dasar laut, peta kenampakan dasar laut dan peta rekomendasi lokasi peletakan anjungan minyak lepas pantai yang dilampirkan dengan skala $1: 6000$.

\section{B. Pembahasan}

1) Analisa Rekomendasi Lokasi Peletakan Anjungan Minyak Lepas Pantai Terhadap Data Batimetri

Analisa dari data batimetri meliputi slope (kemiringan) dasar laut. Pembuatan slope dasar laut berdasarkan data batimetri yang diolah menjadi kontur sehingga menghasilkan slope. Analisa slope dasar laut mengacu pada United State Soil System Management (USSSM) (Verstappen 1953, dalam Ali Agus 2014). Kemiringan (slope) tersebut selanjutnya diberi skor sesuai dengan kemiringannya masing-masing.

Tabel 1.

Skor Kemiringan Dasar Laut Lokasi Penelitian

\begin{tabular}{lrl}
\hline \hline $\begin{array}{c}\text { Kemiringan } \\
\text { Dasar Laut }\end{array}$ & Skor & Keterangan \\
\hline$<1^{\circ}$ & 1 & Datar \\
$1^{\circ}-3^{\circ}$ & 2 & Agak Landai \\
\hline \hline
\end{tabular}




\begin{tabular}{lll}
\hline \hline $3^{\circ}-6^{\circ}$ & 3 & Landai \\
$6^{\circ}-9^{\circ}$ & 4 & Agak Curam \\
$9^{\circ}-25^{\circ}$ & 5 & Curam \\
$25^{\circ}-26^{\circ}$ & 6 & Sangat Curam \\
\hline \hline
\end{tabular}

Hasil data batimetri menunjukkan bahwa kedalaman daerah penelitian berkisar antara kedalaman 93 meter sampai 100 meter. Nilai kedalaman tersebut menunjukkan bahwa bentuk topografi yang cenderung landai.

Peletakan anjungan minyak lepas pantai diletakkan pada kemiringan $\leq 3^{\circ}$ atau berada pada kondisi antara datar sampai agak landai, sementara kemiringan dasar laut yang berada $>3^{\circ}$ tidak direkomendasikan untuk peletakan anjungan minyak lepas pantai. Adanya perbedaan slope yang tinggi merupakan penghalang untuk peletakan platform.

2) Analisa Rekomendasi Lokasi Peletakan Anjungan Minyak Lepas Pantai Terhadap Data Seabed Features

Berdasarkan hasil Peta seabed features didapatkan bahwa pada lokasi penelitian terdapat potensi bahaya yang dapat membahayakan platform, yaitu:

\section{a. Individual Pockmark}

b. Pockmark Cluster

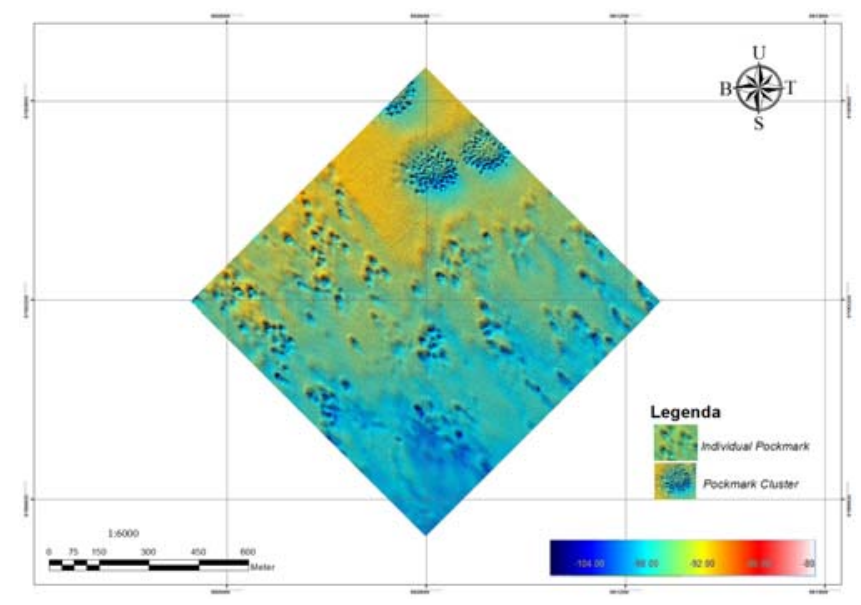

Gambar 3. Peta Kenampakan Dasar Laut

Dari hasil peta kenampakan dasar laut dapat diketahui bahwa terdapat 110 individual pockmark. Individual pockmark terbesar adalah IP 59 yang berada pada koordinat 561065,$72281 ; 9190136,05285$ yang memiliki luas $1516 \mathrm{~m}^{2}$ dan keliling $167.074 \mathrm{~m}$. Sedangkan individual pockmark terkecil adalah IP 12 yang berada pada koordinat 560278,$82952 ; 9190302.32411$ yang memiliki luas $50 \mathrm{~m}^{2}$ dan keliling $27.455 \mathrm{~m}$.

Dari hasil peta kenampakan dasar laut dapat diketahui bahwa terdapat 3 pockmark cluster. Pockmark cluster terbesar adalah PC 1 yang berada pada koordinat 560777,92511 ; 9190641,09910 yang memiliki luas $14963 \mathrm{~m}^{2}$ dan keliling 468,768 m. Sedangkan pockmark cluster terkecil adalah PC 3 yang berada pada koordinat 560526,93066; 9190800,32307 yang memiliki luas $5057 \mathrm{~m}^{2}$ dan keliling $317,545 \mathrm{~m}$.

Daerah penelitian ditemukan banyak sekali pockmark baik individual pockmark maupun pockmark cluster. Jika anjungan minyak lepas pantai mengenai pockmark tersebut akan sangat membahayakan operasional platform.
Berikut ini merupakan pemberian skor untuk hazard berikut:

Tabel 2.

Skor Area Pockmark

\begin{tabular}{lr}
\hline \multicolumn{1}{c}{ Fitur Dasar Laut } & Skor \\
\hline Terdapat Pockmark & 1 \\
Bebas Pockmark & 0 \\
\hline \hline
\end{tabular}

3) Analisa Peletakan Anjugan Minyak Lepas Pantai Terhadap Data Magnetometer

Analisa peletakan anjungan minyak lepas pantai dengan menggunakan magnetometer berdasarkan nilai magnetik yang terekam pada instrumen. Nilai magnetik pada daerah penelitian berada antara 44610,645 nT sampai dengan $44647,168 \mathrm{nT}$.

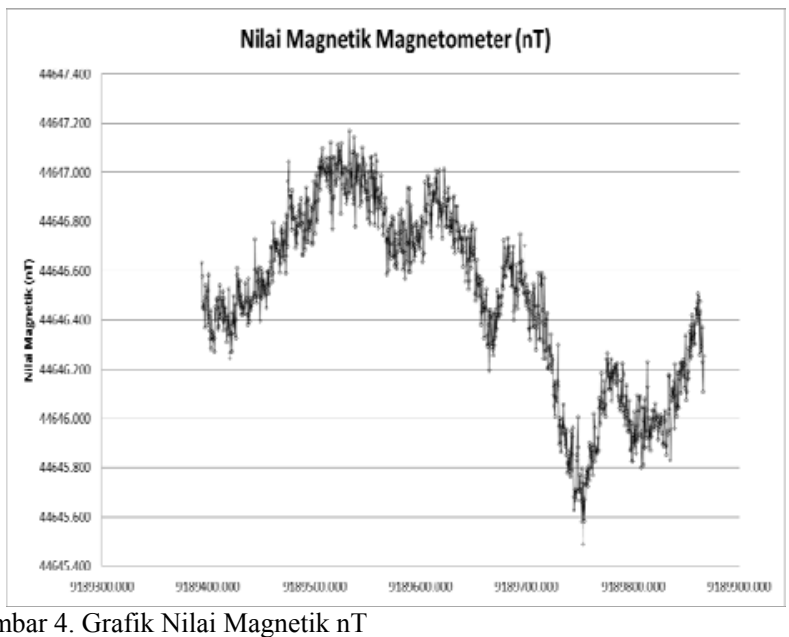

Analisa data magnetometer menggunakan nilai magnetik pada setiap jalur survei. Jika terdapat perubahan pada nilai magnetik tiap jalur survei maka itu disebut dengan anomali magnetik.

Hasil pengolahan data magnetometer, tiap-tiap jalur survei tidak mengalami perubahan nilai magnetik yang drastis maka dapat dikatakan bahwa daerah penelitian bebas dari logam yang berada di permukaan dasar laut maupun terkubur pada dasar laut.

Tabel 3.

Skor Area Anomali Magnet

\begin{tabular}{|c|c|}
\hline Medan Magnet & Skor \\
\hline Ada Anomali Magnet & 1 \\
\hline Tidak Ada Anomali Magnet & 0 \\
\hline
\end{tabular}

\section{Pembobotan}

Pembobotan masing-masing parameter menggunakan metode Analytical Hierarcy Process (AHP) dengan software Expert Choice.

Berdasarkan pembobotan menggunakan analisa AHP, proses selanjutnya adalah menentukan lokasi yang dapat 
direkomendasikan untuk peletakan anjungan minyak lepas pantai.

Tabel 4.

Skor Parameter Kriteria

\begin{tabular}{cccc}
\hline \hline No & Parameter & Besaran & Skor \\
\hline \multirow{4}{*}{1} & Kemiringan Lereng Dasar & $<1^{\circ}$ & 1 \\
& Laut (Slope) & $1^{\circ}-3^{\circ}$ & 2 \\
& & $3^{\circ}-6^{\circ}$ & 3 \\
& Pockmark & Ada & 1 \\
& & Tidak Ada & 0 \\
3 & \multirow{3}{*}{ Anomali Magnetik } & Ada & 1 \\
& & Tidak Ada & 0 \\
\hline \hline
\end{tabular}

Untuk mendapatkan lokasi tersebut digunakan formula berikut ini:

$$
\begin{aligned}
\text { Area Lokasi }= & \left(\text { Skor }_{\text {kriteria } 1} \times \text { Bobot }_{\text {kriteria } 1}\right)+ \\
& \left(\text { Skor }_{\text {kriteria } 2} \times \text { Bobot }_{\text {kriteria } 2}\right)+ \\
& \left(\text { Skor }_{\text {kriteria } 3} \times \text { Bobot }_{\text {kriteria } 3}\right) \ldots
\end{aligned}
$$

Gambar 10. Rumus Skor dan Bobot

Berdasarkan pembobotan tersebut dihasilkan 3 kelas lokasi yaitu lokasi yang aman dan direkomendasikan, lokasi yang tidak direkomendasikan dan lokasi yang berbahaya dan tidak direkomendasikan.

Tabel 5.

Klasifikasi Lokasi dan Skor Penentu

\begin{tabular}{ll} 
& Klasifikasi Lokasi dan Skor Penentu \\
\hline \hline Nilai Skor & Keterangan \\
0.333 & Aman dan Direkomendasikan \\
$0.333-0.666$ & Tidak Direkomendasikan \\
$0.666-1.332$ & Bahaya \\
\hline \hline
\end{tabular}

Tabel 6.

Luas Area Lokasi Berdasarkan Kriterianya

\begin{tabular}{lll}
\multicolumn{3}{c}{ Luas Area Lokasi Berdasarkan Kriterianya } \\
\hline \hline Nilai Skor & Luas $\left(\mathrm{m}^{2}\right)$ & Keterangan \\
\hline 0.333 & $532.216,047$ & Aman dan \\
& & Direkomendasikan \\
$0.333-0.666$ & $379.529,360$ & Tidak direkomendasikan \\
$0.666-1.332$ & $85.227,185$ & Bahaya \\
\hline \hline
\end{tabular}

\section{KESIMPULAN}

Kesimpulan yang dapat diambil dari penelitian ini tentang optimasi peletakan anjungan minyak lepas pantai menggunakan multibeam echosounder, side scan sonar, dan magnetometer adalah sebagai berikut:

1. Lokasi penelitian memiliki elevasi tanah yang landai, sehingga rekomendasi peletakan anjungan minyak lepas pantai berada pada kemiringan dasar laut sampai $3^{\circ}$.

2. Potensi bahaya disekitar lokasi peletakan anjungan minyak lepas pantai meliputi individual pockmark dan pockmark cluster.
3. Tidak ditemukan adanya indikasi logam baik yang berada di permukaan dasar laut maupun terkubur pada dasar laut.

4. Lokasi yang direkomendasikan untuk peletakan anjungan minyak lepas pantai adalah yang memiliki skor 0.333 0.666, dan lokasi yang tidak direkomendasikan dengan skor 0.334-0.666 dan lokasi yang berbahaya dengan skor $0.667-1.332$

\section{DAFTAR PUSTAKA}

[1] Lekkerkerk, H.-J., Velden, RR.v., Haycock, T., P., Vries, R. d., Waalwijk, P. v., et al. 2006. Handbook of Offshore Surveying Volume One: Preparation \& Positioning. London: Clarkson Research Service Limited.

[2] Mandasari, Sindi, 2013. Studi Kelayakan Lokasi Rencana Peletakan Jack-Up Drilling Rig Menggunakan Hasil Pencitraan Side Scan Sonar . S1 - Skripsi Institut Teknologi Sepuluh Nopember

[3] Djunarsah, E., Poerbandono. 2005. Survey Hidrografi. Bandung : Refika Aditama

[4] Dinas Hidro-Oseanografi, 2013. Data Pasang Surut Tide Tables. Jakarta: Jawatan Hidro-Oseanografi TNI-AL.

[5] Masrukhin, Muhammad Ali. 2014. Studi Batimetri dan Morfologi Dasar Laut Dalam Penetuan Jalur Peletakan Pipa Bawah Laut. Semarang : Departemen Ilmu dan Teknologi Kelautan UNDIP. 